\title{
Detection of Clostridium septicum Hemolysin Gene by Polymerase Chain Reaction
}

\author{
Shotaro TAKEUCHI, Naoko HASHIZUME, Takafumi KINOSHITA, Toshio KAIDOH, and Yutaka TAMURA ${ }^{1)}$ \\ Department of Bioscience, Faculty of Biotechnology, Fukui Prefectural University, 4-1-1 Kenjojima, Matsuoka, Fukui 910-11 and \\ ${ }^{1)}$ National Veterinary Assay Laboratory, 1-15-1 Tokura, Kokubunji, Tokyo 185, Japan \\ (Received 15 April 1997/Accepted 26 May 1997)
}

ABSTRACT. A polymerase chain reaction (PCR) was developed for the detection of the hemolysin (alpha toxin) gene of Clostridium septicum. The PCR primers were designed from the sequence of the hemolysin gene and synthesized. A DNA fragment of 270 bp was amplified from 10 strains of $C$. septicum, but was not from strains of $C$. chauvoei, $C$. perfringens, $C$. novyi, or $C$. haemolyticum. When the PCR product was digested with Sau3AI, two DNA fragments of the expected $148 \mathrm{bp}$ and $122 \mathrm{bp}$ were recognized. The lowest detectable threshold of PCR for the hemolysin gene was $3.8 \times 10^{3}$ cells $/ \mathrm{m} l$. The PCR technique may be useful for rapid detection or identification of C. septicum associated with malignant edema. - KEY wORDS: alpha toxin, Clostridium septicum, PCR.

J. Vet. Med.Sci. 59(9): 853-855, 1997

Clostridium septicum is a causative agent of malignant edema in animals and gas gangrene in human. The organism is closely related to Clostridium chauvoei which causes blakleg in cattle and sheep $[17,21]$. These species produce four major toxins (alpha, beta, gamma and delta toxins) that correspond to each other in biological activity. Moreover, they possess common antigens, which are detected by a complement fixation test, immunofluorescence and enzymelinked immunosorbent assay [9, 11, 15]. At present, the diagnosis of the diseases by these organisms is confirmed by clinical symptoms, detection of toxins, and isolation and identification of the organisms. However, these procedures are complexity and take several days to complete.

The polymerase chain reaction (PCR) is a molecular genetic technique for in vitro amplification of specific nucleic acid sequences. By this technique, organisms can be detected and identified directly from clinical specimens or environmental samples. Recently, PCR has been used for the detection of toxin genes, including neurotoxins of $C$. botulinum type A to $\mathrm{F}[4-7,18-20]$, major toxins and enterotoxin of $C$. perfringens $[3,10,16]$, and toxin A of $C$. difficile [8, 13-14].

In the present study, we report the development of a PCR technique which will rapidly and specifically detect the gene for hemolysin (alpha toxin) of C. septicum. The PCR technique may be useful for rapid detection or identification of $C$. septicum associated with malignant edema in cattle.

The bacteria used in this study are listed in Table 1 , including 10 strains of $C$. septicum, 6 strains of $C$. perfringens, 4 strains of $C$. chauvoei, 2 strains of $C$. novyi, and 1 strain of $C$. haemolyticum. Clinical isolates of Staphylococcus aureus and Actinomyces pyogenes were also used. All organisms, except $S$. aureus, were cultivated anaerobically at $37^{\circ} \mathrm{C}$ for $18 \mathrm{hr}$ by the $\mathrm{CO}_{2}$ gas jet method, modified by Azuma and Suto [1] from the original description of Hungate.

After centrifugation, the bacterial cells were resuspended in $1.5 \mathrm{ml}$ of TES buffer $(10 \mathrm{mM}$ Tris- $\mathrm{HCl}, 1 \mathrm{mM}$ EDTA, $150 \mathrm{mM} \mathrm{NaCl}$ ) containing $25 \%(\mathrm{~W} / \mathrm{V})$ sucrose and $2 \mathrm{mg} / \mathrm{m} l$ lysozyme and incubated at $37^{\circ} \mathrm{C}$ for $1 \mathrm{hr}$. Then, $150 \mu \mathrm{l}$ of $10 \%$ SDS solution was added to the suspension and it was incubated at $37^{\circ} \mathrm{C}$ for $10 \mathrm{~min}$. The lysed cell suspension was diluted with $3 \mathrm{~m} l$ of TES buffer. Nucleic acids in the diluted cell suspension were extracted twice with phenol and once with phenol/chloroform/isoamyl-alcohol (50/48/2) and then precipitated with ethanol. After drying, the precipitates were dissolved in $100 \mu l$ of TE buffer and used for the template DNA.

From the sequence of $C$. septicum hemolysin gene reported by Imagawa et al. [12], two oligonucleotides were synthesized as primers to amplify a DNA fragment of 270 bp. The sequences of the synthesized primers were 5'AATTCAGTGTGCGGCAGTAG-3' (nucleotides 611-630) and 5'-CCTGCCCCAACTTCTCTTTT-3' (complementary to nucleotides 880-861).

PCR amplification was performed in a total of $100 \mu \mathrm{l}$ containing $10 \mu \mathrm{g}$ of the template DNA, $20 \mathrm{pmol}$ of each primer, $2.5 \mathrm{mM}$ of the four deoxynucleotides, and 2.5 units of Taq polymerase (Takara Shuzo Co., Ltd.). The reaction mixtures were overlaid with mineral oil and subjected to 35 cycles of amplification in a PCR thermal cycler (Takara Shuzou Co., Ltd.). Each amplification cycle performed was at $94^{\circ} \mathrm{C}$ for $1 \mathrm{~min}$ for denaturing, at $55^{\circ} \mathrm{C}$ for $1 \mathrm{~min}$ for annealing, and at $72^{\circ} \mathrm{C}$ for $1 \mathrm{~min}$ for extension. After amplification, the PCR products were analyzed by agarose gel electrophoresis.

Figure 1A shows the electrophoretic pattern of the PCR products obtained from 10 strains of $C$. septicum. The 270 bp band of the hemolysin gene was obtained in reference strains (lanes 1 to 7) and clinical isolates (lanes 8 to 10). These PCR products were digested with restriction enzyme Sau3AI and electrophoresed. As shown in Fig. 1B, two bands of the expected lenghts (148 and 122 bp) were recognized. This result indicates that the PCR products did indeed arise from the sequence of hemolysin gene of $C$. septicum.

Imagawa et al. [12] mentioned that the nucleotide sequence of the $C$. septicum hemolysin was unique, because no significant sequence homology has been found between this gene and the GenBank and EMBL nucleotide sequence data base, including the toxins of $C$. perfringens or Streptococcus pyogenes. On the other hand, Bourgeau et al. [2] cloned and sequenced the gene for alpha toxin of $C$. septicum BX96. In addition, they found that the DNA- 
A

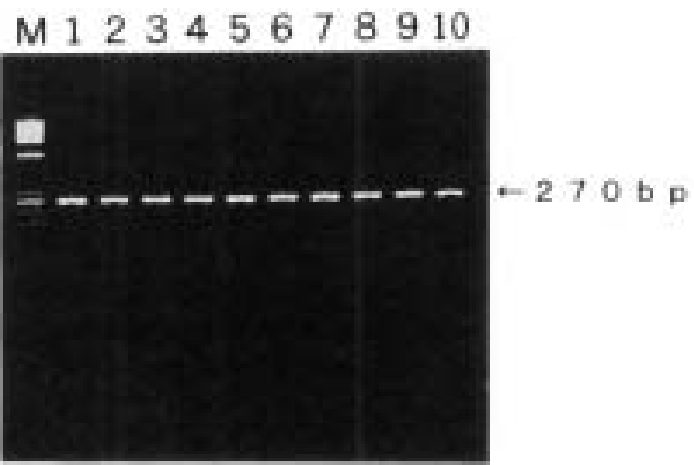

B

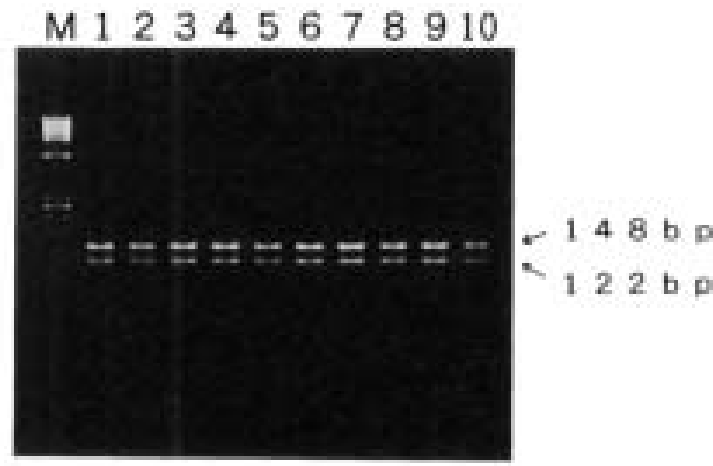

Fig. 1. Agarose gel electrophoresis. (A) The PCR products from C.septicum. (B) The PCR products restricted with Sau3AI. Lanes 17: reference strains (NCTC 281, NCTC 282, NCTC 286, NCTC 501, NCTC 504, NCTC 551, NCTC 12464), lanes 8-10: clinical isolates (44, Chiba, Miyazaki), M: molecular marker.

derived primary sequence of alpha toxin exhibited $27 \%$ identy with aerolysin of Aeromonas hydrophila over a contiguous region of 387 amino acids.

In the present study, the DNA fragment of $270 \mathrm{bp}$ was not amplified from $C$. perfringens, C. chauvoei, $C$. haemolyticum, C. novyi, A. pyogenes or S. aureus, which produce various hemolytic toxins (Table 1). Also in a DNA sequence homology research, significant sequence homology could not be find between our primers and A. hydrophila aerolysin (M29818), A. hydrophila alpha hemolysin (L36462), Aeromonas salmonicida beta hemolysin (X65049), Bacillus cereus hemolysin (U94743), $C$. perfringens perfringolysin O (M36704), Listeria monocytogenes listeriolysin (U25443), Paenibacillus alvei alveolysin (M62709), Pseudomonas paucimobilis beta hemolysin (L01270), S. aureus alpha hemolysin (M90536), S. aureus beta hemolysin (X13404), Streptococcus canis streptolysin O (D16825), Streptococcus equisimilis streptolysin O (D16824), or Streptococcus pneumoniae pneumolysin (M17717). From the results, it seems that the PCR technique is specific for the hemolysin gene of $C$. septicum.

The lowest detectable threshold of the PCR for the hemolysin gene was examined as follows. After overnight cultivation, bacterial cell numbers were determined by direct microscopic count with a hemocytometer (Thoma type). After that, the culture fluid was centrifuged and resulting cells were resuspended in TES buffer. The cell suspension was diluted serially 10 -fold with TES buffer and heated at $95^{\circ} \mathrm{C}$ for $10 \mathrm{~min}$. After centrifugation, the supernatant was used as a template. As a result, a positive DNA band of hemolysin gene was observed in PCR products ranging from $3.8 \times 10^{1}$ to $3.8 \times 10^{5}$ cells, but not from $3.8 \times 10^{0}$ cells per $10 \mu \mathrm{l}$ sample (data not shown). The result indicates that the lowest detectable threshold is $3.8 \times 10^{1}$ cells per $10 \mu l(3.8$ $\times 10^{3}$ cells $\left./ \mathrm{m} l\right)$.

For the detection of $C$. septicum in organs, the culture fluid of $C$. septicum was inoculated intraperitonealy into a
Table 1. List of bacterial strains, source and the results of PCR

\begin{tabular}{llc}
\hline Bacterial strains & Source & PCR results \\
\hline Clostridium septicum & NCTC 281 & + \\
Clostridium septicum & NCTC 282 & + \\
Clostridium septicum & NCTC 286 & + \\
Clostridium septicum & NCTC 501 & + \\
Clostridium septicum & NCTC 504 & + \\
Clostridium septicum & NCTC 551 & + \\
Clostridium septicum & NCTC 12464 & + \\
Clostridium septicum & isolate (44) & + \\
Clostridium septicum & isolate (Chiba) & + \\
Clostridium septicum & isolate (Miyazaki) & + \\
Clostridium chauvoei & ATCC 10092 & - \\
Clostridium chauvoei & ATCC 11957 & - \\
Clostridium chauvoei & isolate (C6H) & - \\
Clostridium chauvoei & isolate (Okinawa) & - \\
Clostridium novyi & ATCC 19402 (type A) & - \\
Clostridium novyi & ATCC 25758 (type B) & - \\
Clostridium haemolyticum & ATCC 9650 & - \\
Clostridium perfringens & isolate (C-1) & - \\
Clostridium perfringens & isolate (C-2) & - \\
Clostridium perfringens & isolate (B-1) & - \\
Clostridium perfringens & isolate (B-2) & - \\
Clostridium perfringens & isolate (E-1) & - \\
Clostridium perfringens & isolate (E-2) & - \\
Actinomyces pyogenes & isolate (42) & - \\
Staphylococcus aureus & isolate (CH-91) & - \\
\hline & & \\
\hline
\end{tabular}

mouse. After $24 \mathrm{hr}$ inoculation, the mouse was sacrificed and its heart, lung, liver, kidney and spleen was harvested. These organs were triturated in $1 \mathrm{ml}$ of TE buffer in a glass homogenizer and then heated at $95^{\circ} \mathrm{C}$ for $10 \mathrm{~min}$. After centrifugation, the resulting supernatants were used in the PCR amplification as a template. However, the $270 \mathrm{bp}-$ band of hemolysin gene was not detected in these organs. Moreover, the inoculated organism was not recognized in the homogenized organs by Giemsa's staining. Therefore, C. septicum was added in the homogenized organs of other mouse to a final concentration of $5 \times 10^{3}$ cells $/ \mathrm{m} l$ and then 
heated at $95^{\circ} \mathrm{C}$ for $10 \mathrm{~min}$. After centrifugation, the resulting supernatants were used in the PCR amplification. As a result, the 270-bp band of hemolysin gene was observed in heart and lung, but was not in liver, spleen and kidney (data not shown). From the result, it is conjectured that inhibitors in enzymatic reaction of PCR amplification exist in the liver, spleen and kidney of mice. Therefore, futher study is necessary to remove the inhibitors for the direct detection of C. septicum in organs by the PCR technique.

\section{REFERENCES}

1. Azuma, R. and Suto, T. 1970. Proc. 1st. Int. Conf. Cult. Collect. : 493-505.

2. Bourgeau, G., Lapointe, H., Peloquin, P., and Mayrand, D. 1992. Infect. Immun. 60: 3186-3192.

3 Daube, G., China, B., Hvala, K., and Mainil, J. 1994. J. Appl. Bacteriol. 77: 650-655.

4. Fach, P., Gibert, M., Griffais, R., Guillou, J. P., and Popoff, M. R. 1995. Appl. Environ, Microbiol. 61: 389-392.

5. Ferreira, J. L., Baumstark, B. R., Hamdy, M. K., and Mccay, S. G. 1993. J. Food Prot. 56: 18-20.

6. Franciosa, G., Ferreira, J. L., and Hatheway, G. L. 1994. J. Clin. Microbiol. 32: 1911-1917.

7. Franciosa, G., Fenicia, L., Caldiani, C., and Aureli, P. 1996. J. Clin. Microbiol. 34: 882-885.

8. Gumerlock, P. H., Tang, Y. J., Weiss, J. B., and Silva, J. Jr. 1993. J. Clin. Microbiol. 31: 507-511.

9. Hamaoka, T. and Terakado, N. 1994. J. Vet. Sci. 56: 371373.
10. Havard, H. L., Hunter, S. E. C., and Titball, R. W. 1992. FEMS Microbiol. Letters 97: 77-82.

11. Hiramune, T., Kobayashi, Y., Nakazawa, M., Watase, H., and Hashimoto, K. 1979. Bull. Natl. Inst. Anim. Health Jpn. 78: 15-18 (in Japanese).

12. Imagawa, T., Dohi, Y., and Higashi, Y. 1994. FEMS Microbiol. Lettes 117: 287-292.

13. Kato, N., Ou, C. Y., Kato, H., Bartley, S. L., Brown, V. K., Dowell, V. R. Jr., and Ueno, K. 1991. J. Clin. Microbiol. 29: 33-37.

14. Kato, N., Ou, C. Y., Kato, H., Bartley, S. L., Luo, C. C., Killgore, G. E., and Ueno, K. 1993. J. Infect. Dis. 167: 455458.

15. Poxton, I. R. and Byrne, M. D. 1984. J. Med. Microbiol. 122: 41-46.

16. Saito, M., Matsumoto, M., and Funabashi, M. 1992. Inter. J. Food Microbiol. 17: 47-55.

17. Smith, L. DS. and Williams, B. L. 1984. pp. 164-175. In: The Pathogenic Anaerobic Bacteria, 3rd ed.(Balows, A. ed.), Charles C. Thomas Publisher, Sprinfield, IIIinois.

18. Szabo, E. A., Pemberton, J. M., Gibson, A. M., Thomas, R. J., Pascoe, R. R.R., and Desmarchelier, P. M. 1994. J. Clin. Microbiol. 32: 1986-1991.

19. Szabo, E. A., Pemberton, J. M., Gibson, A. M., Eyles, M. J., and Desmarchelier, P. M. 1994. J. Appl. Bacteriol. 76: 539545 .

20. Takeshi, K., Fujinaga, Y., Inoue, K., Nakajima, H., Oguma, K., Ueno, T., Sunagawa, H., and Ohyama, T. 1996. Microbiol. Immunol. 40: 5-11.

21. Willis, A. T. 1969. Clostridia of Wound Infection. Buterworths, London. 